\title{
遺伀了涪断と治燎の倫理
}

试篎监

\section{Bioethics of Gene Diagnosis and Gene Therapy}

by

Hiraku Takebe, D.SC.

from

Department of Life Science, School of Science \& Technology, Kinki University

Ethics committees were established in all medical universities and colleges in Japan in the late 1980s. New medical methods, both in basic research as well as in clinical practice, required ethical consideration. A guideline for bioethics in research on the human genome and gene analyses was laid out by the government in 2001 .

The guideline is contradictory in certain principles with international guidelines such as those established by WHO. The difference might be caused by lack of human genetics in medical education in Japan. Genetic counseling, which is emphasized in the government guideline, is not practiced, mainly due to a lack of well-trained genetic counselors. An urgent program to promote the education of human genetics in medical schools as well as in general education is needed. Gene therapy should be limited to the cure of diseases, not for the "improvement" of non-disease characteristics. Diversity in human genes should be kept intact, as human beings are but one of the nature's species.

(Received September 24, 2002 ; accepted October 29,2002)

Key $\boldsymbol{u}$ ords : binethics, human genome, ethical guidelines, informed consent, genetic counseling

Jpn J Neurosurg (Tokyo) 12:143-146, 2003

\section{はじめに}

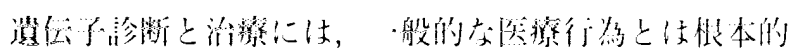

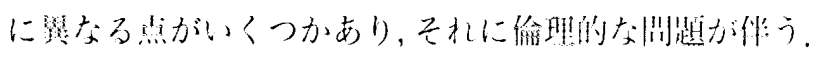

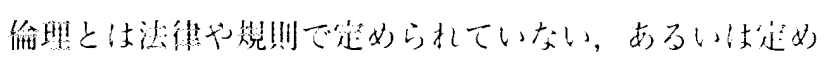

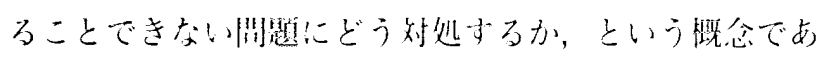

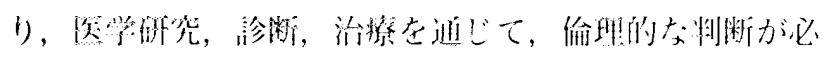

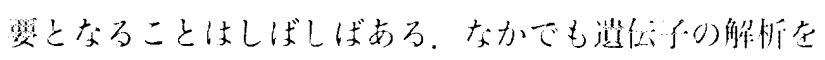

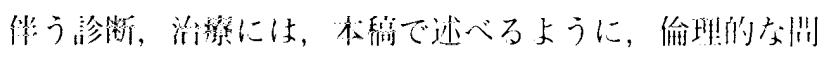

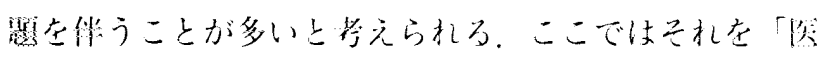

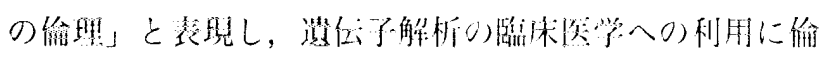

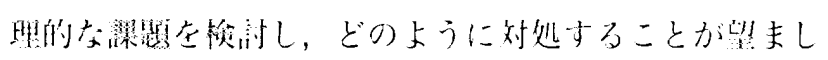

$$
\text { いか在考えたい。 }
$$

\section{医の倫理の歴更 なぜ聚近蹰視されるようになってきたのか}

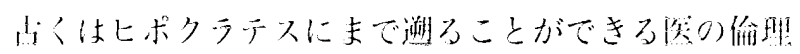

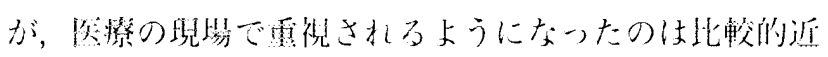
俳のことであり，1960 年代のアメリカから起こったとさ

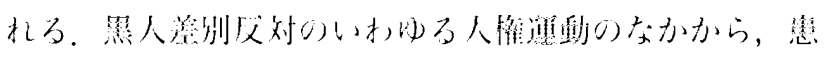

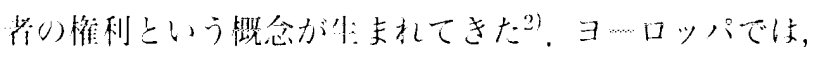

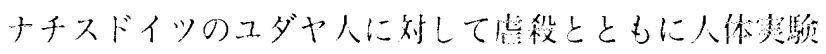

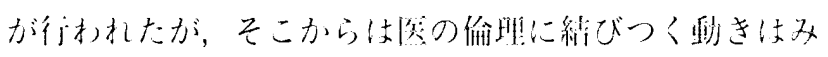

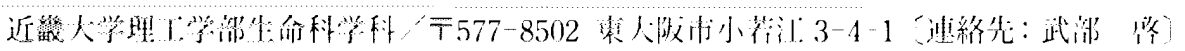

Address reprint requests to: Hiraku Takebe, I.Sc., Department of Life Science, School of Science \& Technology, Kinki Universiy, 3-

4-1 Kowakae, Higashiosaka - shi, Osaka 577-8502, Japan 
ら和ず，アメリカの動き在進う上うに，休外授精や移

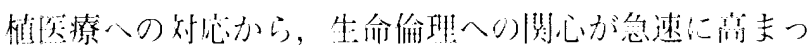

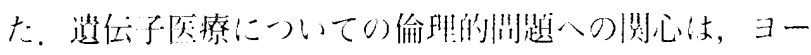

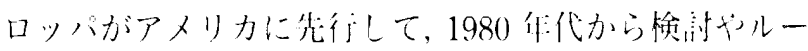
ル件りを進めてきた。このように20 世糺末に急に海の

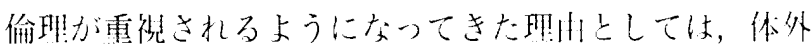

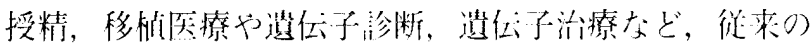

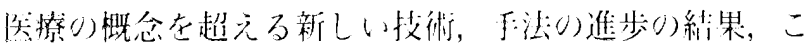

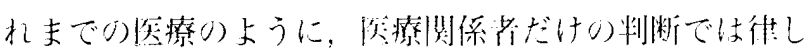

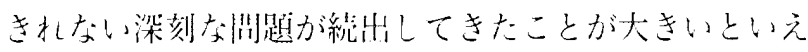

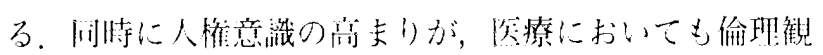

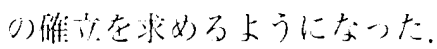

\section{日本における医の倫理への関心 倫理観亡倫理委員会}

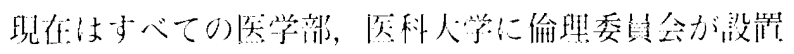

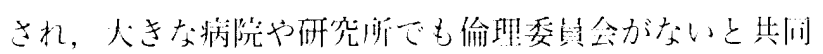
研究などに参川できない䇛悄になってきている。しかし

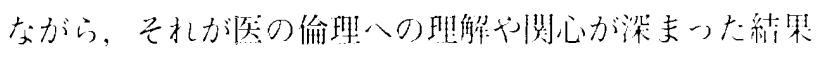

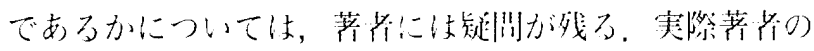

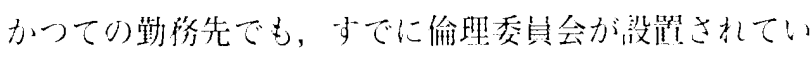
る人学からの転任者在迎えるため，というのが没漼の

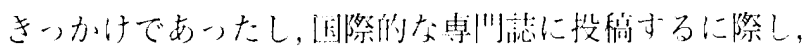

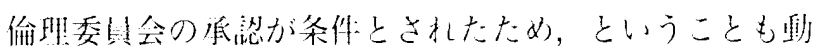
機としてあった。

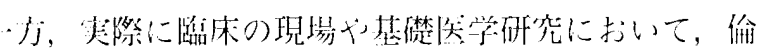

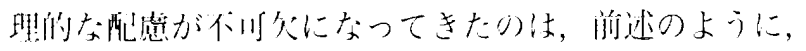

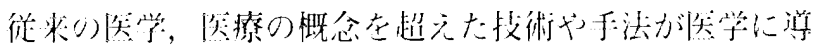
人きれたことが大きな要国であった。また外目で閏発さ

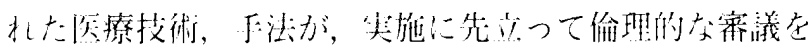

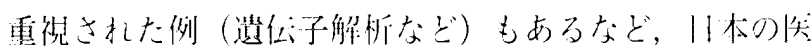

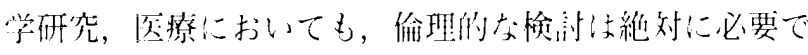

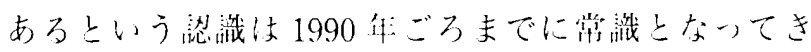
た。

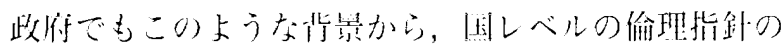

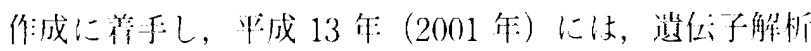

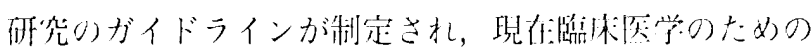

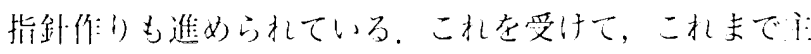

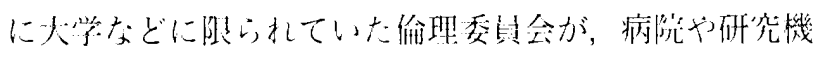

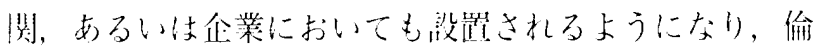

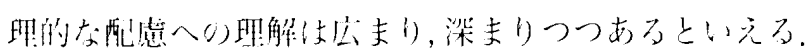

\section{どのような倫理的譯題があるのか

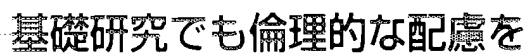

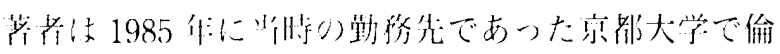
理秋只に就㭛して以米，今川末で被数の倫理委員会に参 㞦してきた。また目際的にはヒトゲノム解析国際機構

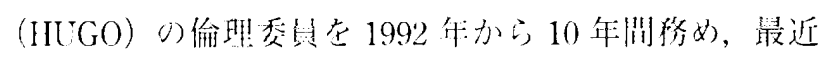

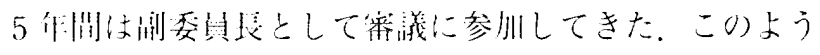

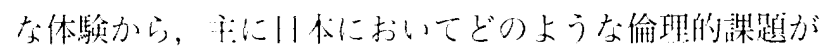
あるつか在考えたい。

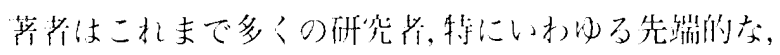

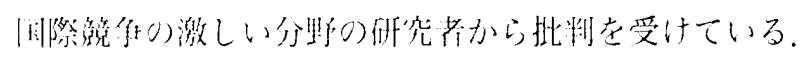

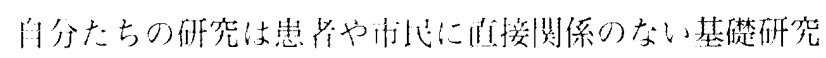

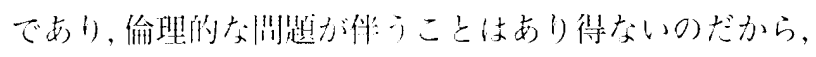

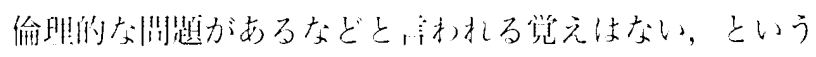
のが其通した市牌である。

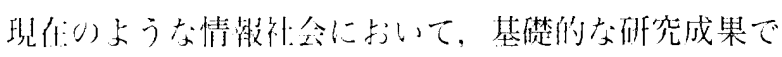

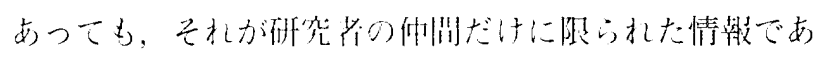
ることはありえない。分川ではインターネット在通じて， だ扎でも最新の哭術情翰（原落渝文在含む）に接するこ とボでき，研究少だけの狄い补会の情城ではなくなって Wr.

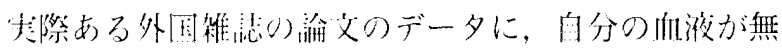
断で使わ扎ていたことの华発が・州民からあって，大き

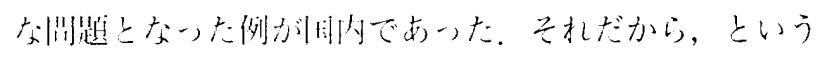
のでは六く，省のインフォームド・コンセントという慨

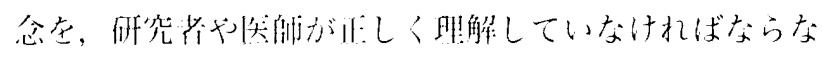

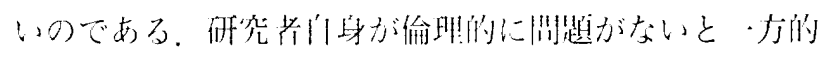

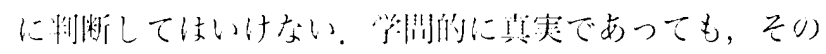

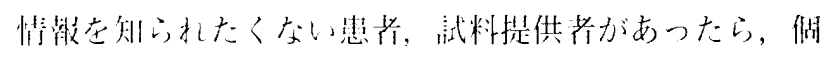

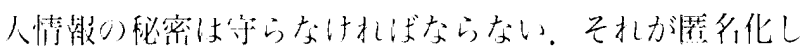

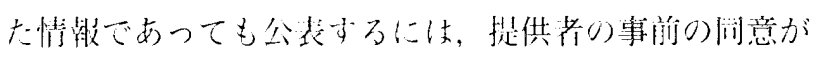

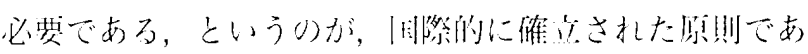
万.

\section{国際的な倫理基準と日本の指針との相違点}

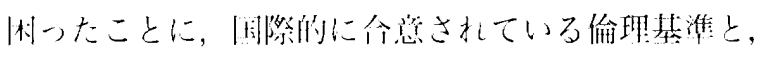

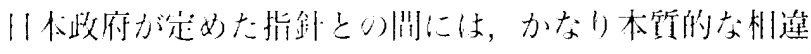

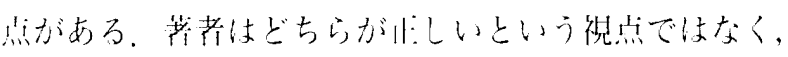
なぜ去の上うな湋いが非じたか，について考えたい。

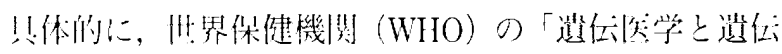

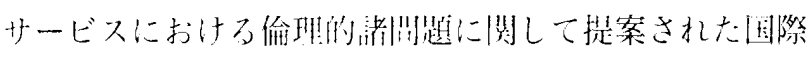
的なガイドライング(1998 仵，以下WHO ガイドライン）

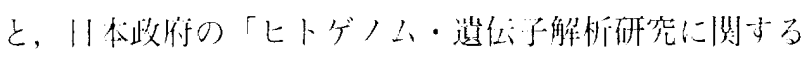




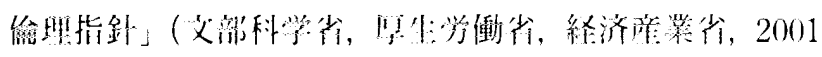

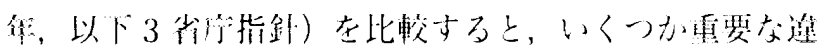

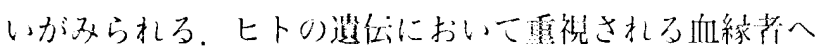

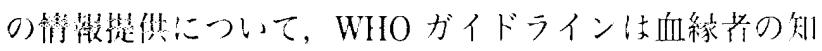
る锥利在当然とし，血糘行が付て死亡するか，速絡が

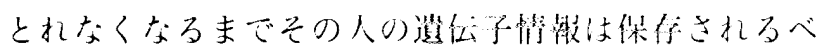

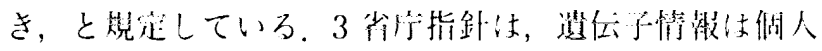

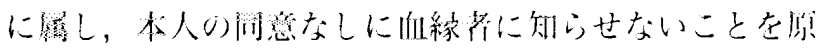

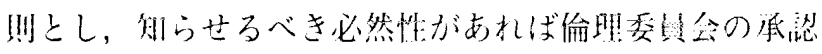
によって知らせる，としている。このことは，頲伝とい

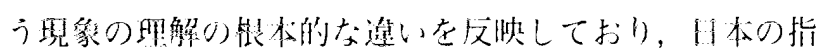

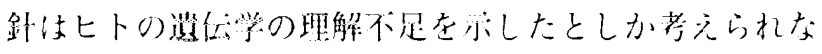

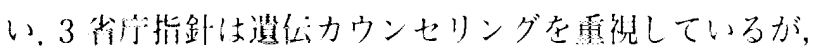

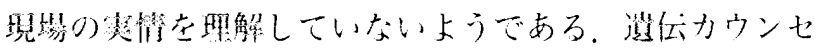

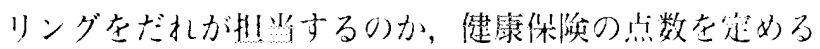
のか，といった奏施の前提となる体制がまったくできて いない現状では，架究の議論でしかない，选伝かウンセ

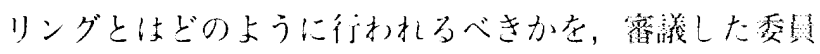
会が任とんど理解していなかったのでは交いだつうか。

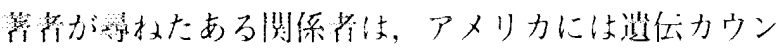
七ラーか約 1,000 人いると閉いているが，目本には500 人いるそうだから㤋できるのではないか，と佥った。

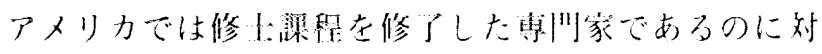

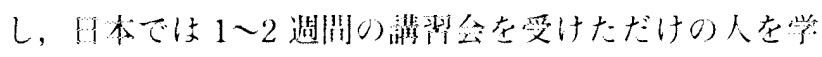

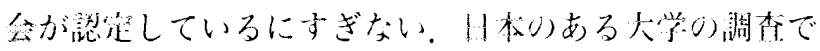

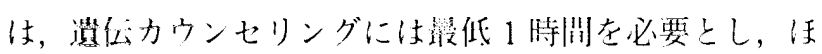

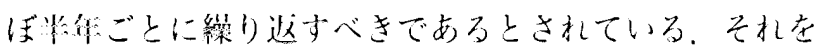

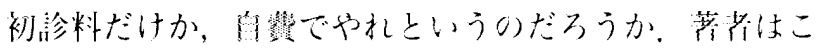
の上うな初步的な润骨与以埋解していないとしかいえな

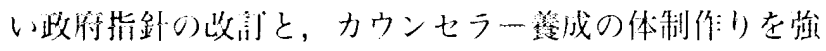
く求めたい。

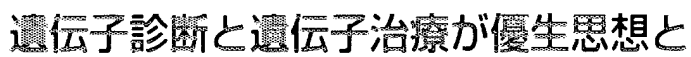 結びついてはいけない}

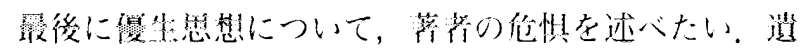

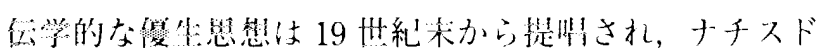
イッによってユダヤ人やジプシーとよばれた人々の䖉殺

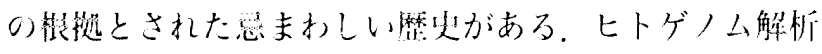

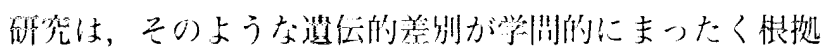
がないことを时確に亦したのである。ところが，选伀子

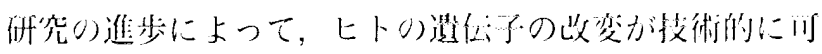

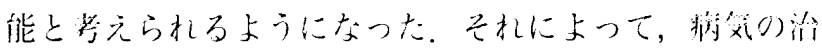

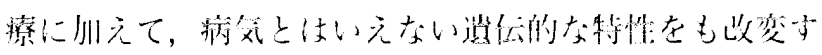

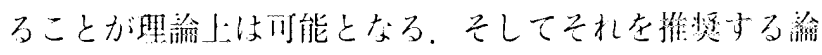
㼁すらすでに起こっている゙3.

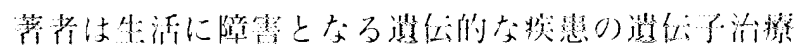

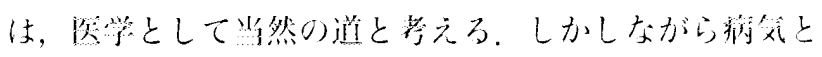

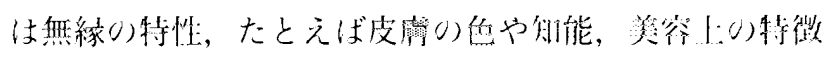

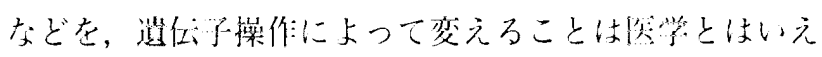

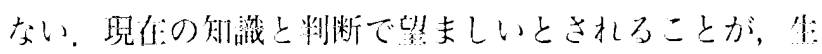

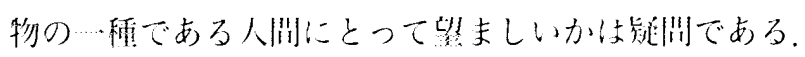

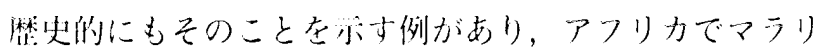

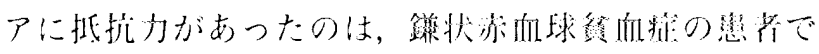

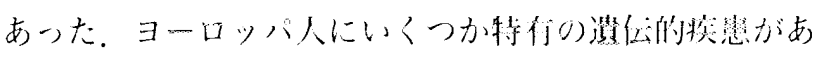

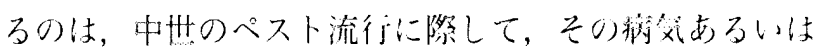
その遗伀子の保们者が批抗性であったためではないか， との铞がある。

\section{おわりに}

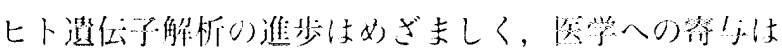

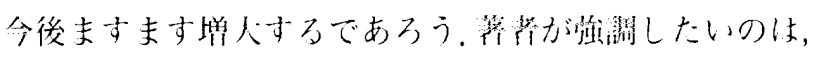

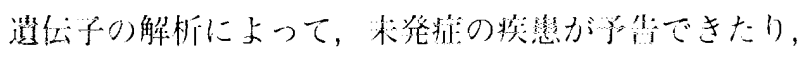

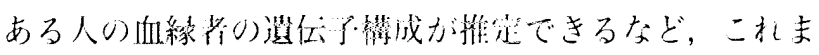

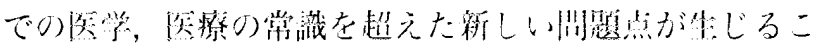

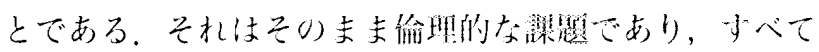

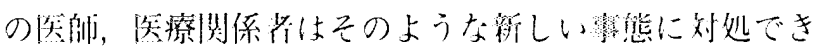
ることが望末扎る。11本兴神終外科コングレス総公にお

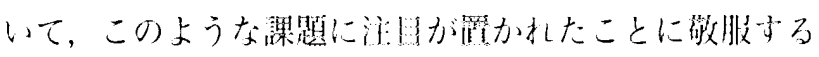

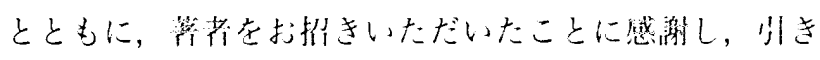

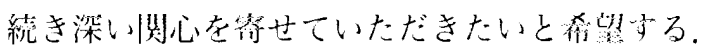

\section{文 㚋}

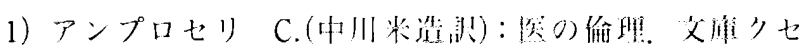
ジュ，案宗，白水祇， 1993.

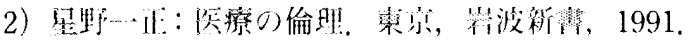

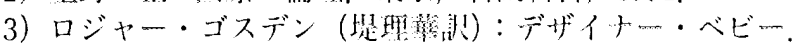

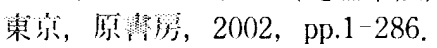

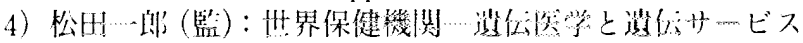

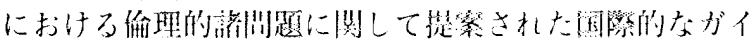

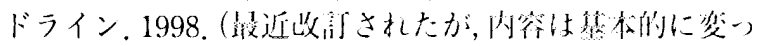

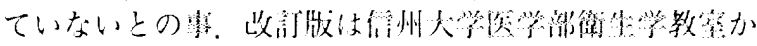
ら人チできる． 


\section{要每}

\section{遺伝子診断と治療の倫理}

武部啓

日本において，医の倫理が重視されるようになったのは，1980 年代の終わりごろからであり，遺伝 子研究については，さらに遅れて，政府から研究のための指針が示されたのは 2001 年であった。 そ れは国際的な医の倫理の重視の動きによるとともに，移植や遺伝子操作などの医療技術の進歩によっ て，従来の医学の概念では判断できない問題が生じてきたことにもよる，日本政府の指針は，それ以 前に公表されている国際的な指針（ガイドライン）等と比較すると，かなり本質的な違いがみられる が，日本の突情に合った指針が望ましい。

今日のような情報化社会では，爵門家だけでなく，一般市民にも理解が得られる倫理観が医療の世 界に求められることを，医学研究者や医療従事者は認識しなければならない，

脳外誌 $12: 143-146,2003$

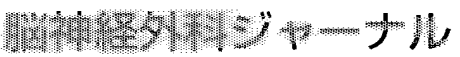
Exำ

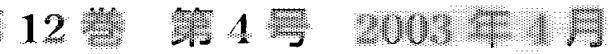

本誌 12 巻 4 号は, 第 23 回日本脳神経外科コングレスプログラムおよび抄録となります. 学会当日は抄録号は改めて男叠いたしませんので本誌 4 号を持参して下さい.

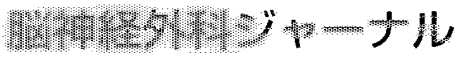

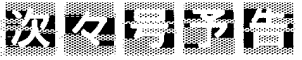

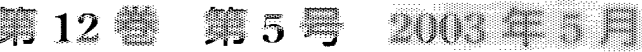

原著

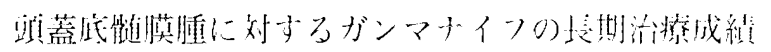

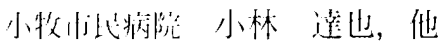

総 説

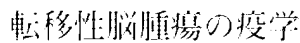

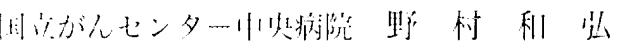

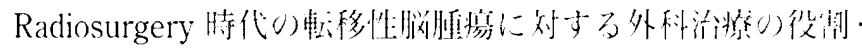

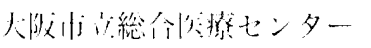
岩井溓命，他

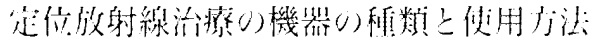

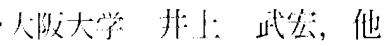

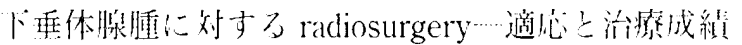

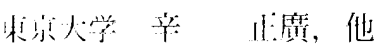

㲁動脈病変の内科的汸撚

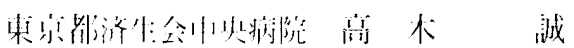

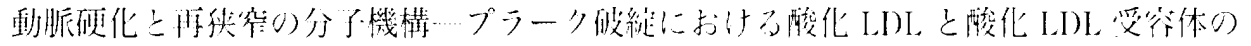

役制在中心に

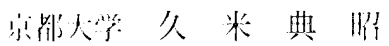
症例報告 